\title{
Grass Seedling Emergence and Survival after Treatment with Fungicides ${ }^{1}$
}

\section{A. C. HULL, JR. AND K. W. KREITLOW ${ }^{2}$}

Range Scientist, Plant Science Research Division, Agricultural Research Service, U. S. Department of Agriculture, Logan, Utah; and Agricultural Administrator, Plant Science Research Division, Agricultural Research

Service, U. S. Department of Agriculture, Beltsville, Maryland.

\section{Highlight}

Thiram, Captan and Semesan were used to treat seeds of intermediate wheatgrass, tall oatgrass and smooth brome, seeded in spring and fall for 5 years, and to treat seeds of crested and intermediate wheatgrasses seeded for 3 years at a second location. The same fungicides were used to treat grass seeds at 3 rates in two studies in the greenhouse. Kind or rate of fungicide treatment did not significantly influence seedling emergence in the greenhouse. Averaging the two field areas, Thiram treatments gave significant increases over the check of $14 \%$ in emergence and $20 \%$ in survival. Captan treatments gave significant increases of $12 \%$ in emergence and survival. Semesan increases were not significantly better than the check.

On the basis of greenhouse and freezing chamber tests in California, Laude (1956) concluded that soil pathogens reduced the emergence of six perennial grasses, especially during prolonged cold weather. Ehrenreich (1958) applied Arasan, Orthocide 75, and Dithane Z-78 in the greenhouse and in the field to seed of 6 species used for range seeding in Colorado. All treated seed produced more established seedlings than untreated controls. Kreitlow and Bleak (1962) found that a soil-borne fungus (Podosporiella verticillata) reduced grass seedling emergence and vigor over much of the western United States. Infection and damage were most severe at lower elevations on sagebrush sites. No infection was observed in aspen-fir sites.

On mountainous rangelands in southeastern Idaho there is low emergence and high mortality of smooth brome and intermediate wheatgrass seedlings (Hull, 1966). This study was initiated to determine if seed treatment with fungicides would improve grass seedlings emergence and survival on these rangelands.

${ }^{1}$ Cooperative investigations of Plant Science Research Division, Agricultural Research Service, U.S. Department of Agriculture; Forest Service, U.S. Department of Agriculture; Utah Department of Fish and Game; and Utah Agricultural Experiment Station. Utah Agricultural Experiment Station Journal Paper 906. Received October 5, 1970.

2 The authors thank those who assisted with the field phases of the study, and those who made helpful comments on the manuscript. We are particularly grateful to Arvel T. Bitters, who did much of the field work, and to E. James Koch, who made the statistical analyses.

\section{Description of Experimental Sites}

The first experimental site is in Franklin Basin in southeastern Idaho. It is located in a weedy area approximately 1,000 acres in size within the spruce-fir type. The elevation of this area is $8,400 \mathrm{ft}$. with an annual precipitation of 47 inches. Snow usually covers the area from early November to early June. The dominant vegetation is tarweed (Madia glomerata Hook.) (Fig. 1). The soil is clay loam, low in organic matter and plant nutrients with a $\mathrm{pH}$ from 5.6 to 5.8. The soil compacts and hardens soon after snow melt. This not only reduces but slows seedling emergence, giving seeds and seedlings a longer period of exposure to soil pathogens. Examination of dead and dying grass seedlings on this area in 1960 and 1961 suggested that soil pathogens were contributing to the death of grass seedlings. However, no pathological investigations were conducted with affected seeds or seedlings.

The sccond cxperimental arca is located near Logan, Utah. This is a formerly dryland cultivated bench area now supporting a thick stand of annual weeds with scattered plants of alfalfa (Medicago sativa L.). At settlement, the original vegetation was undoubtedly sagebrush and bunchgrasses. The area is at $4,800 \mathrm{ft}$. elevation with an annual precipitation of 17 inches. The soil is a deep, productive Timpanogas silt loam with scattered small rocks through the top 4 feet.

\section{Procedures}

Grasses treated with fungicides were: crested wheatgrass (Agropyron desertorum (Fisch.) Schult.), intermediate wheatgrass (A. intermedium (Host) Beauv.), tall oatgrass (Arrhenatherum elatius (L.) Presl), and smooth brome (Bromus inermis Leyss.). Intermediate wheatgrass, tall oatgrass, and smooth brome were sown at Franklin Basin and crested and intermediate wheatgrasses at Logan.

Seeds of each species were treated just prior to seeding with each of 3 fungicides: Thiram (Arasan)-Tetramethylthiuram disulfide; Captan-(Orthocide 75) N-trichloromethylthio-4-cyclohexene-1,2-dicarboximide 75\%; and Semesan-Hydroxymercurichlorophenol $30 \%$ (Mercury equivalent $19 \%$ ). ${ }^{3}$ The fungicides were applied separately to the seed for each plot. Each specics had control plots where no fungicide was applied to the seed. Fungicides and seeds were shaken together in a bottle and the excess fungicide was removed by rolling the treated seed down an inclined fine mesh screen. The ounces of each fungicide that would adhere to $100 \mathrm{lb}$. seed of each species was calculated from 4 replicates of 200 grams of seed of each species:

\begin{tabular}{lccc}
\hline \multicolumn{1}{c}{ Species } & Thiram & Captan & Semesan \\
\hline Smooth brome & 10.8 & 10.8 & 10.7 \\
Crested wheatgrass & 11.1 & 10.7 & 10.2 \\
Intermediate wheatgrass & 10.3 & 10.4 & 9.9 \\
Tall oatgrass (dehulled) & 9.4 & 8.3 & 9.6 \\
\hline
\end{tabular}

Seedbeds were prepared by plowing and harrowing. A hand cone seeder drilled seeds to an approximate depth of .75 inch at the average rate of 25 viable seeds per foot. Each plot was a row 10 feet long and 1 foot apart. There were 4 replications of each treatment. Seeding rates were

${ }^{3}$ Mention of a manufactured product does not imply endorsement by the U.S. Department of Agriculture over other companies or products not mentioned. 


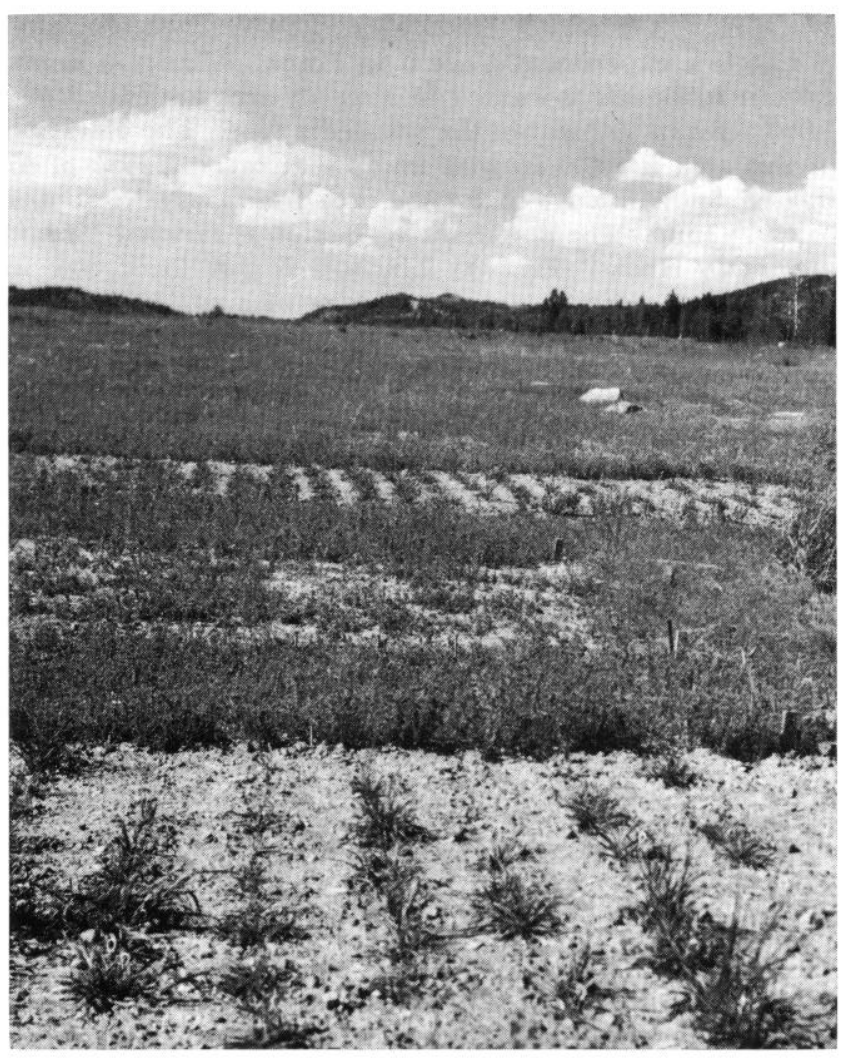

FIg. 1. General view of Franklin Basin. Foreground is right angle view of 3 strips of seeded plots with fungicidal treatments. Strips between plots and the background are the native tarweed. August, 1962.

$6 \mathrm{lb}$ /acre for crested wheatgrass; 11 for intermediate wheatgrass; 7 for tall oatgrass; and 8 for smooth brome.

At Franklin Basin, seedings were made each spring and fall from the fall of 1961 through the spring of 1966, except for the fall of 1962. At Logan, spring and fall seedings were made from the spring of 1964 through the spring of 1966 . Spring seedings were made as soon as possible after spring snow melt and fall seedings about 1 month prior to permanent winter snow. At Franklin Basin this was usually early June and late September. Logan seedings were made mid April and late October.

We counted seedlings as emergence was near complete but before mortality commenced. This was usually 4 weeks after the first emergence. We also counted plants in early spring and late fall the first growing season, and in late fall the second growing season.

We also tested different rates of the same 3 fungicides applied to seeds in two greenhouse studies. In the first study all fungicides were applied at 4, 12, and $20 \mathrm{oz} / 100 \mathrm{lb}$. seed on each of 3 species; crested wheatgrass, tall oatgrass and smooth brome. In the second study, intermediate wheatgrass was added to make 4 grasses and rates of fungicides were reduced with Captan at 4, 8, and $16 \mathrm{oz} / 100 \mathrm{lb}$. seed and Thiram and Semesan at 3, 6, and 12 ounces. Seeds were moistened enough for the desired amounts of fungicide to adhere.

A soil similar to Franklin Basin soil was used for the first study and soil from Franklin Basin for the second. Soil was placed in greenhouse flats and treated and untreated seeds
Table 1. Number of seedlings $/ \mathrm{ft}^{2}$ emerging and seedlings $/$ ft. $^{2}$ surviving the second year at Franklin Basin and Logan. Species, seasons and years averaged.

\begin{tabular}{llclll}
\hline \hline \multirow{2}{*}{ Fungicides } & \multicolumn{2}{c}{ Franklin } & Basin & & \multicolumn{2}{c}{ Logan } \\
\cline { 2 - 3 } \cline { 5 - 6 } \cline { 5 - 6 } Thiram & Emerg. & Surv. & & Emerg. & Surv. \\
Captan & $3.50^{\mathrm{a}} *$ & $1.01^{\mathrm{a}}$ & & $6.06^{\mathrm{a}}$ & $2.86^{\mathrm{a}}$ \\
Semesan & $3.37^{\mathrm{a}}$ & $.93^{\mathrm{ab}}$ & & $6.04^{\mathrm{a}}$ & $2.67^{\mathrm{ab}}$ \\
Control & $3.04^{\mathrm{ab}}$ & $.83^{\mathrm{bc}}$ & & $6.24^{\mathrm{a}}$ & $2.78^{\mathrm{ab}}$ \\
\hline
\end{tabular}

* For emergence and survival, any 2 means followed by the same letter are not significantly different at the $5 \%$ level.

were sown 0.5 inch deep in single rows in 5 replicated blocks. Seedling emergence was recorded daily for 13 days and then every 3 to 5 days until emergence stopped. Significance of field and greenhouse results at the $5 \%$ level was determined by Duncan's (1955) multiple range test.

\section{Results and Discussion}

Damage from soil-borne pathogens is influenced by prevalence and destructiveness of the pathogen, and by susceptibility and vigor of the host. Both pathogen and host are affected by soil characteristics, temperature and moisture. Thus, substantial variation in injury from soil-borne pathogens can occur seasonally. This in turn influences the effectiveness of fungicides to control disease on treated seeds. At Franklin Basin, for example, the soil compacts rapidly after snow melt. This slows seedling emergence which in turn encourages the development of pathogens.

Statistical analyses of results of field tests showed considerable variation among and between locations, years, seasons, species and fungicides. Variations can be expected because uncontrolled variables such as frost heaving, compact soils, drought, heat, cold, and insects may influence results. To get the average response of fungicides, all variables were pooled in analyses (Table 1). At Franklin Basin, both mean seedling emergence and number of surviving plants of Thiram and Captan treated seeds were significantly greater than for the control. At Logan, the seeds from all three fungicide treatments produced significantly greater numbers of seedlings than did the untreated controls. However, only Thiram treated seeds had a significantly greater number of surviving plants than the control.

Averaging both areas, Thiram seed treatment significantly increased mean seedling emergence by $20 \%$ and survival by $14 \%$ over the control. Captan treatment significantly increased emergence and survival by $12 \%$. Semesan treatment showed but slight improvement over the control.

Under greenhouse conditions all species from all treatments commenced to emerge 6 days after planting in study 1 and 5 days in study 2 . Seedlings 
stopped emerging 26 days after seeding in study 1 and 27 days in study 2 . There was no significant difference in rate of emergence or in final emergence of seeds treated with any fungicide or rate of fungicide when compared to the control. In the greenhouse, seeds germinate and seedlings emerge without many of the stresses normally encountered in the field. In these tests, growing seeds in field soil, possibly low in pathogen potential, along with greenhouse growing conditions favorable for rapid seedling emergence, may have obscured the modest benefit from seed treatment observed in the field.

\section{Conclusions}

Based on conditions of this study, fungicidal seed treatment did not improve seedlings emergence in the greenhouse. In the field, however, fungicides increased emergence and survival. Averaging both areas, Thiram seed treatment significantly increased emergence and survival as compared to the control. Captan increases were smaller but still significant.
Semesan gave little response. Treating seeds with fungicides is relatively inexpensive. It would, therefore, be worthwhile to treat grass seeds with recommended fungicides, particularly in areas where difficulty in establishing grass seed stands has been encountered.

\section{Literature Cited}

Duncan, David B. 1955. Multiple range and multiple F tests. Biometrics 11:1-42.

EHRENREICH, JoHN H. 1958. Effects of certain fungicides on seed germination and seedling establishment of range forage plants. J. Range Manage. 11:22-27.

HuLl, A. C., JR. 1966. Emergence and survival of intermediate wheatgrass and smooth brome seeded on a mountain range. J. Range Manage. 19:297-283.

Kreitlow, K. W., and A. T. Bleak. 1964. Podosporiella verticillata, a soil-borne pathogen of some western gramineae. Phytopathology 54:353-357.

Laude, Horton M. 1956. The seedling emergence of grasses as affected by low temperatures. Agron. J. 18: $558-560$. 